Vol-VI, Issue-02, (July-December, 2011) \& Vol-VII, Issue-1 (January-June, 2012)

\title{
Bangladesh Financial Reporting Standard (BFRS) and Environmental Accounting: A Case Study of Listed Manufacturing Companies in Bangladesh
}

\author{
MD. ISLAM BISWAS* \\ MD. MUSTAFIZUR RAHAMAN ${ }^{* *}$
}

\begin{abstract}
This paper examines whether Bangladesh Financial Reporting Standards (BFRS) can be used for monitoring environmental degradations. The paper critically examines the contemporary environmental accounting literature, and attempts to find a mandatory reporting mechanism in the context of accounting for a public good. It selects the relevant financial reporting standards and examines their strengths and weaknesses. Using qualitative and case-study research methods, the financial statements of 65 local manufacturing companies that are operating in an environmentally sensitive sector are studied. The study finds that the Global Reporting Initiative's (GRI) guidelines and the private sector's self-regulation are insufficient to monitor environmental disclosure. The paper proposes a mandated separate statement of environmental assets and liabilities. The elements of the proposed statement are discussed.
\end{abstract}

Key words: BFRS, GRI, Environmental Accounting, Environmental Assets and Liabilities, Bangladesh.

\section{INTRODUCTION}

As financial globalization proceeds, international financial reporting and auditing standards are increasingly becoming important instruments of integration. This has been observed in Cannes summit of the G20 leaders in November 2011. The G20 leaders reinforced the influence of International Financial Reporting Standards (IFRS) and in that they called for the implementation of global accounting standards by 2011. By the end of 2008,

\footnotetext{
*Lecturer, Department of Accounting, Bangladesh University of Business \& Technology (BUBT), Dhaka

${ }^{* *}$ Lecturer, Department of Accounting, Bangladesh University of Business \& Technology (BUBT), Dhaka
} 
there were over 100 countries that had adopted IFRS (Cabrera, 2008; Barth, et al 2008). Another parallel summit was the "Business for the Environment Global Summit 2011" which was held in Indonesia on 27-29 April 2011. The Global summit offers collaborative solutions to address the most urgent environmental and climate issues facing the world today. This paper makes a critical appraisal of the contemporary environmental accounting literature, and examines whether Bangladesh Financial Reporting Standards (BFRS) can contribute towards the monitoring and protection of the environment of the country.

A quick glance through the conceptual framework and a number of standalone standards provide useful grounds for monitoring environmental assets, liabilities and expenditures. Furthermore, since accounting is characterized by recognition, measurement and disclosure, mandated accounting for the environment brings accountability to the boardroom. Added to this is the fact that BFRS has legal backing throughout the country, and hence it has a unique advantage of bringing environmental accountability into both financial markets and regulatory frameworks.

This paper uses a conceptual schema to synthesize causes and effects of environmental degradations, and argues that BFRS is necessary for monitoring the environmental behaviour of various firms. Bangladesh financial reporting and auditing standards will be able to discriminate among the beauty contestants in environmental disclosures. The nonfinancial and financial information can be reported through a mandatory separate statement of environmental assets and liabilities. This paper proposes some of the elements of such a statement.

A cluster of research argues that the firm's environmental disclosure effort is a self serving exercise of obtaining social legitimization. This study searches for a framework in BFRS so that environmental risks (liabilities, litigations, reputation damages, loss of future profits) and assets (endowments, rights and known reserves) of public and private goods can be accounted for. The paper identifies key standards that are relevant to environmental monitoring, and suggests ways of integrating financial and nonfinancial information into the existing financial reporting system.

\section{RELEVANT LITERATURE}

The literature on the environment is multidisciplinary and impenetrable. This research paper makes a critical appraisal of the contemporary environmental accounting literature and examines whether International Financial Reporting 
Standards (IFRS) can contribute towards the monitoring and protection of the environment. Haripriya (2000) has delineated four non-mutually exclusive environmental accounting systems, including pollution expenditure accounting, physical accounting that measures the stocks of environmental assets over time, Green indicators - a system closely linked to conventional GDP measure and adjusted to the Nordhaus-Tobin measure of economic welfare and the United Nation's System of National Accounts (SNA). The environmental Economics literature analyzes welfare measurement, sustainability, technological change, externality and "green accounting" within the framework of general equilibrium models (Aronsson, Johansson and Lofgren; 1997). Lange (2003) demonstrates the link between "environmental accounting" and "sustainable development". According to him, environmental accounting research purports to find indicators of potential pollutant industries, and suggests policies on how best to regulate these industries. Furthermore, Lange (2003:11) links the discussion on "sustainable development" to inter-generational altruism, and goes after the world commission on environment and development (aka the Brundtand Commission, 1987) which in turn states that "sustainable development is meeting the needs of the present generation without compromising the ability of future generations to meet their own needs."

Barth and McNichols (1994) have examined whether the stock market values environmental liabilities and clean up costs. Klasson and McLaughlin (1996) have used event study methodology to examine the link between financial performance and environmental performance. Konar and Cohen (2001) have examined whether there is an association between firm-level environmental performance and intangible assets, and reported that poor environmental performance has a significant negative effect on the intangible-asset value of publicly traded firms. Konar and Cohen (op cit) have argued that major corporations voluntarily over-comply with environmental regulation, and externally portray an image of being environmentally concerned. The authors provide evidence that this image is rewarded.

From a practical-institutional perspective, corporate social and environmental reports appear to be guided by Global Reporting Initiative's (GRI) guidelines rather than IASB standards. The GRI's "triple bottom line" reporting, which states that corporate earnings are a function of economic value added, environmental value added and social value added are also advanced by consulting firms. In other words, the focus of mainstream empirical 
research and GRI was on the promotion of voluntary disclosure. Another interesting observation is that, as of late, a variety of sustainability indices that compare listed companies started to emerge. The report assigns the sustainability, reporting responsibility to the audit committee, which often gets outsourced to external audit firms.

From the review of the relevant literature one observes the following. First, as noted earlier, environment is a multidisciplinary study, and setting a coherent set of national and global policy is not an easy task. Second, the Burntland Commission's definition of sustainable development is similar to Hick's definition of economic profit, which states that income is the maximum amount that an individual can consume during the current period, and leave the firm well off at the end of the period as it was at the beginning. Hence, this requires both intergenerational altruism and the conversion of accrual net income figure to economic profit. Third, the environment is partly a private (trade-able) good and partly a public (non trade-able) good. Fourth, to the extent trans-boundary emissions and river systems are affecting the quality and sustainability of life, the environment is also a global (international) good. Hence, in order to prevent market failure and improve allocation efficiency treaties and regulations are necessary. That is, the monitoring problem cannot be resolved through the voluntary disclosure and self regulation mechanism. Hence, the type of accounting that is required for the environment needs to combine concepts of REA accounting (system), SNA, IFRS and accounting for public goods.

\section{RESEARCH-QUESTIONS AND METHODOLOGY}

The study has descriptive research design to fulfil the research purpose. The population of this study comprises of all the listed manufacturing companies in Bangladesh. At present (February, 2012) total number of listed manufacturing companies in Bangladesh are ninety three. For this study secondary data have been used for effective research findings. The data has been collected from annual reports of selected manufacturing companies. The annual reports were collected from the library of the Dhaka Stock Exchange (DSE) and websites of the companies. In addition to the above, the data has been collected through study several relevant standards, articles, national and international study materials and other printed materials. The population and sample has been shown on next page in Table 1 on the basis of various manufacturing sectors. 
TABLE 1

SECTOR WISE POPULATION AND SAMPLE DISTRIBUTION

\begin{tabular}{cll|c|c}
\hline $\begin{array}{c}\text { Sl. } \\
\text { No. }\end{array}$ & \multicolumn{1}{c|}{ Sectors } & Population & Sample & Percentage \\
\hline 1 & Cement & 6 & 4 & 66.67 \\
2 & Ceramics & 5 & 2 & 40.00 \\
3 & Food \& allied & 16 & 10 & 62.50 \\
4 & Fuel \& power & 13 & 10 & 76.92 \\
5 & Jute & 3 & 1 & 33.33 \\
6 & Pharmaceuticals \& & & & \\
& Chemicals & 20 & 15 & 75.00 \\
7 & Tannery industries & 5 & 3 & 60.00 \\
8 & Textile & 25 & 20 & 80.00 \\
& Total & 93 & 65 & 69.89 \\
\hline
\end{tabular}

Hence, the following steps were followed. First, through a causality schema, the paper outlines the factors that are associated with environmental degradation and climate change (Figure 1). Second, the paper analyzes the existing ICAB standards to identify environment related standards/provisions/paragraphs (Table 2). Third, sixty five companies, listed in DSE, that operate in environmentally sensitive sectors were selected (Appendix01). The 2010-11 annual reports of the selected companies were studied. Fourth, the paper examined whether it is feasible to prepare a standardized and auditable separate statement for the environment (Table 3).

\section{CONCEPTUAL RELATIONSHIP AND BFRS}

\subsection{Conceptual Schema}

Figure 1 is drawn following the conventions of structural equation modelling. In order to improve the readability of the figure, certain connectors (associations) between nodes and mathematical notations were omitted or reduced to the minimum. Note that there are five nodes in Figure 1 - emission, production, depletion, projects and urbanization. Each node in turn contains multiple factors.

For instance, the emission node has factors from X11 to X1n, and X11 can represent $\mathrm{Co} 2$ or an equivalent element that contributes to emission of pollutants that affect air and water quality. The production node in turn has multiple factors ranging from $\mathrm{X} 21$ to $\mathrm{X} 2 \mathrm{n}$. The nodes and the rest of the factors can be identified by carefully reviewing ISO and other industry standards and the emerging 
literature. $\eta \mathrm{i}$ is a policy node that is caused by activities (X11 to Xnn) that lead to emission, production, depletion, large projects and urbanization activities. The policy node is further mediated by market and nonmarket forces. Market forces are product, labour and financial markets (including financial intermediaries in carbon securities) while nonmarket forces are state and non-state actors.

FIGURE 1: Conceptual Schema

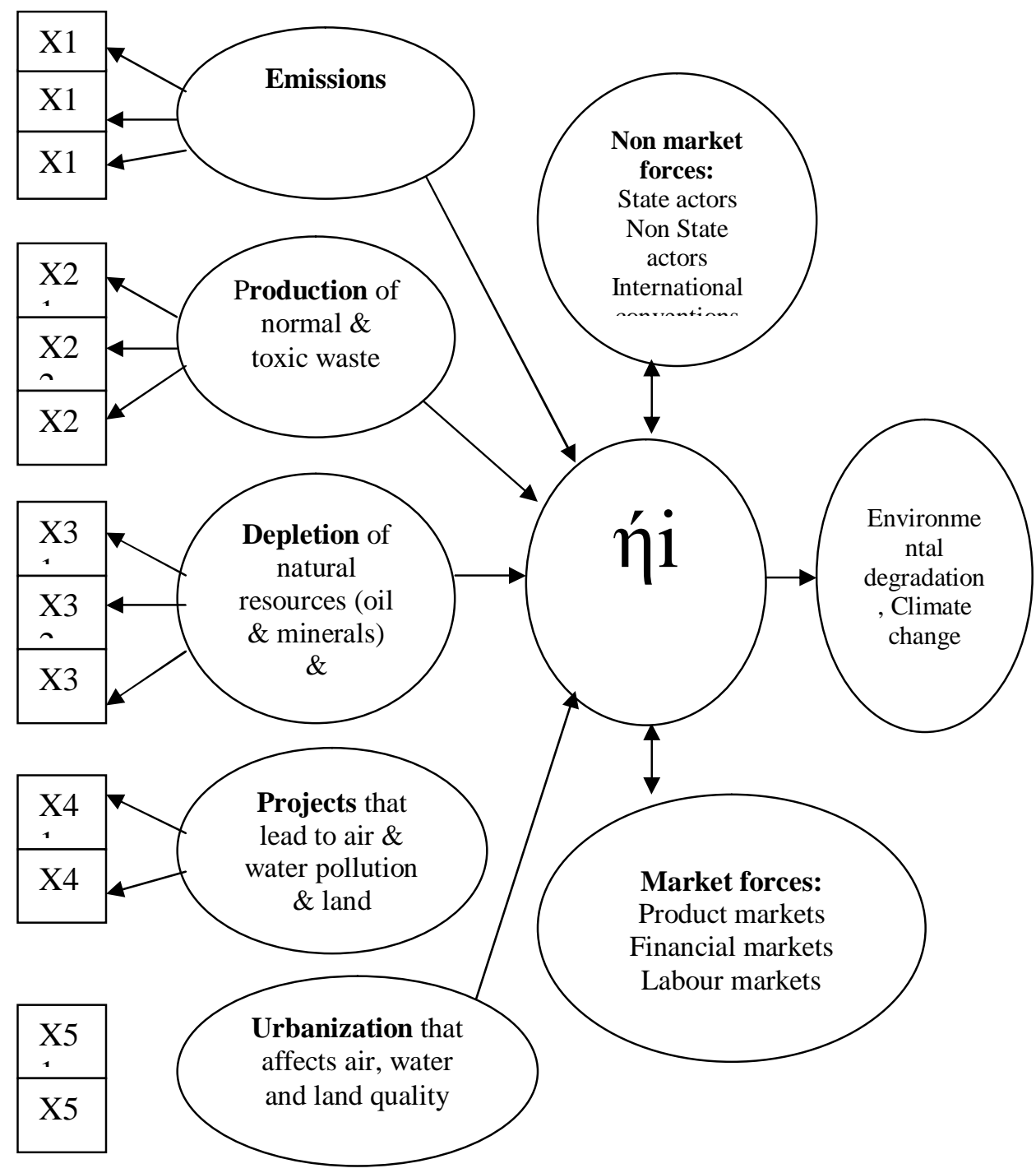


Another important question is it necessary to delineate the trans-boundary causes of environmental degradation from the non-trans-boundary causes? The interesting question for this paper is the extent to which accounting policy makers can influence the policy node, of good local and international environmental governance.

\subsection{Relevant financial reporting standards}

As noted earlier, a number of existing standards and interpretations directly and indirectly deal with environmental issues. In this respect, BFRS 6 (implementation January 2007) for example directly deals with extractive industries and IFRIC 5 provides the guidance for decommissioning, rehabilitation and restoration of environment related expenditure. IFRIC 3 (still under discussion) and BAS 38 (intangibles) deal with government allocated emission rights, trades in these rights and the impairment of the emission allowances. Furthermore, it is important to note that a number of other standards provide an indirect support for the recognition, measurement and disclosure of environmental assets and liabilities. BAS 37 (provisions for contingent liabilities and assets) can be linked to environmental liabilities. BFRS 3, BAS 27, BAS 28, BAS 31, BAS 24 and BFRS 8 respectively deal with business combinations, investments in joint ventures and associates, related party disclosures, and specify the reportable segments of a geographically dispersed global company. Listed local manufacturing companies, subject to certain exemptions, are expected to comply with BFRS. An environment perspective to financial reporting standards therefore provides a new insight; an insight that is useful for monitoring and protecting the environment. The relevant standards are discussed below.

Paragraph 11 of BFRS 6 states the following:

"In accordance with BAS 37 Provisions, continent liabilities and contingent assets, an entity recognizes any obligations for removal and restoration that are incurred during a particular period as a consequence of having undertaken the exploration for and evaluation of mineral resources".

Furthermore, paragraph 3 of BAS 37 defines provisions as "liabilities of uncertain timing or amount"; and contingent liability is defined as "a liability that arises from past events, [italics added] and its existence will be confirmed only by the occurrence and non-occurrence of one or more of uncertain future events that are not wholly within the control of the entity." Paragraph 14 of BAS 37 requires that provision should be recognized when (a) an entity has a present obligation (legal or constructive) as a result of a past event; (b) it is probable that an outflow of resources embodying economic 
benefits will be required to settle the obligations; and (c) a reliable estimate can be made of the amount of the obligation. Paragraph 17 further defines an "obligating event" as a past event that leads to present obligation. It states that for an event to be an "obligating event", it is necessary that the entity has no realistic alternative to settling the obligation created by the event. Finally, paragraph 27 of BAS 37 deals with the disclosure conditions for contingent liabilities. If the liability is not expected to lead to an outflow of resources and where an entity is jointly and severally liable for an obligation, that part of the obligation that is expected to be met by other parties is treated as contingent liability. The standard therefore leaves the application to the management, audit committee and external auditors. In other words, even though the two standards do not define the time limit or the size (amount) of the event or what construes a "constructive" obligating event, they provide the technical ground for the recognition of environmental liabilities that arise from past events (activities) that lead to, for example, the deterioration of air and water quality (see Figure 1).

Rights (allowances) to emit pollutant continue to be treated as intangible assets to be accounted for according to BAS 38 (Intangible Assets). When the rights are allocated by government department for amounts less than its fair value, the difference is recognized as deferred income (liability) in the statement of financial position. When the firm starts polluting, it records provisions according to BAS 37. The original draft did not raise issues about past events.

In its November 2009 meeting of IASB the technicalities of defining an "obligating event" and the timing of recognition of liability at cost or market value and recording of initial government allocation right (at cost of market) and provisions, whether it should be treated as intangible asset and face impairment annual test are finalized. However, the lesson from this IFRIC is that a number of standards BAS 38 (Impairments), BAS 20 (Government Grant), BAS 37 (Provisions, contingent liabilities and contingent assets) and the standards that relate to financial instruments (BAS 32, BFRS 7 and BAS 39) will be affected, and require amendments.

IFRIC 5 (decommissioning, restoration, rehabilitation and similar liabilities) deals with accounting for trust funds set aside for the environment. Paragraph 1 of IFRIC 5 defines the purpose of the fund as "to segregate assets to fund some or all of the costs of decommissioning plants (such as a nuclear plant) or certain equipment (such as cars) or in undertaking environmental rehabilitation (such as rectifying pollution of water or resorting mined land), together referred to as "decommissioning". 
BAS 8 deals with selecting and applying accounting policy. The scope of BAS 8 covers fundamental errors, retrospective adjustments of financial statements (as far back as practicable, per paragraph 26), and when and how material omissions or wrong statements should be practically treated, and corrected. The only unsettled matter is whether the retrospective restatement of financial statements for environmental costs and liabilities is impractical and indeterminate (paragraph 5 of BAS 8).

BFRS 8 also requires firms to disclose their products, services and the geographical areas in which they are operating. Paragraph 13 of BFRS 8 sets the quantitative thresholds of $10 \%$ of combined revenue. However, both paragraph 23 and paragraph 33 are silent about segment risks and rewards arising from engaging in environmentally sensitive activities in each of the geographical areas that the company is operating. When BFRS 8 is examined in conjunction with BAS 27 (consolidation) and the above mentioned standards the implication for global companies operating in environmentally sensitive industries becomes serious.

BAS 32, BFRS 7 and BAS 39 respectively deal with presentation, disclosure, and recognition and measurement of financial instruments. Hedge accounting (cash flow hedge, fair value hedge and hedge of net investment in foreign operations - paragraph 86 and 87 of BAS 39) require that gains and losses, and effective and non effective hedges are to be reported in the comprehensive statement of income. Given the rise of carbon related financial instruments, and increases in pending lawsuits against companies the combined impacts of BAS 27, BAS 37, BFRS 6, IFRIC 5, BAS 8 and standards that deal with derivative instruments are to strengthen the political costs (Watts and Zimmerman, 1986) for global companies that are operating in environmentally sensitive industries.

Table 2 (next page) contains a summary of environment related financial reporting standards. The table identifies relevant terms, phrases and paragraphs. 
TABLE 2

ENVIRONMENT RELATED FINANCIAL REPORTING STANDARDS

\begin{tabular}{|c|c|c|c|}
\hline $\begin{array}{c}\text { BFRS/BAS } \\
\text { number }\end{array}$ & $\begin{array}{l}\text { Title and/ or } \\
\text { description }\end{array}$ & $\begin{array}{l}\text { Relevant paragraph(s). } \\
\text { Paragraph numbers in } \\
\text { parenthesis }\end{array}$ & Remarks \\
\hline Framework & $\begin{array}{l}\text { Framework for } \\
\text { preparation \& } \\
\text { presentation of } \\
\text { financial } \\
\text { statements }\end{array}$ & $\begin{array}{l}\text { Accountability (14), } \\
\text { relevance }(26), \\
\text { materiality }(29 \& 30), \\
\text { substance }(35), \text { neutrality } \\
(36), \text { prudence }(37), \\
\text { completeness (38), } \\
\text { liabilities \& obligation } \\
(60), \text { capital maintenance } \\
(81), \text { probability (85), } \\
\text { measurement reliability } \\
(86), \text { recognition of } \\
\text { liabilities (91) }\end{array}$ & $\begin{array}{l}\text { Statement to the effect } \\
\text { that sustainability is } \\
\text { within the bounds of the } \\
\text { conceptual framework of } \\
\text { IASB and FASB }\end{array}$ \\
\hline BFRS 6 & $\begin{array}{l}\text { Exploration \& } \\
\text { evaluation of } \\
\text { mineral } \\
\text { resources }\end{array}$ & $\begin{array}{l}\text { Paragraph }(11) \text { : } \\
\text { requirement for } \\
\text { provision and } \\
\text { contingencies }\end{array}$ & $\begin{array}{l}\text { Refer to statistics about } \\
\text { emissions; production of } \\
\text { pollutants; toxic waste } \\
\text { disposal systems, ground } \\
\text { water pollution \& land } \\
\text { degradation; depletion, } \\
\text { industrial accidents; } \\
\text { environmental impact } \\
\text { studies. }\end{array}$ \\
\hline $\begin{array}{l}\text { IFRIC } 3 \\
\text { (withdrawn) }\end{array}$ & $\begin{array}{l}\text { Emission rights } \\
\text { and allowances }\end{array}$ & $\begin{array}{l}\text { Several paragraphs deal } \\
\text { with whether } \\
\text { government allocated } \\
\text { rights; and the } \\
\text { accounting treatment at } \\
\text { the start of emission, and } \\
\text { the setting aside of } \\
\text { provisions. }\end{array}$ & $\begin{array}{l}\text { Kyoto Agreement, } \\
\text { Copenhagen Summit; } \\
\text { Agreement versus treaty; } \\
\text { efficiency of national } \\
\text { and global allocation } \\
\text { systems, speculation and } \\
\text { transferability of } \\
\text { emission rights; whether } \\
\text { climate change has o } \\
\text { boundaries; markets for } \\
\text { trading emission and } \\
\text { similar rights and their } \\
\text { derivatives; sovereign } \\
\text { rights; global shared } \\
\text { databases (REA). }\end{array}$ \\
\hline
\end{tabular}

Cont. Table 2 


\begin{tabular}{|c|c|c|c|}
\hline $\begin{array}{c}\text { BFRS/BAS } \\
\text { number }\end{array}$ & $\begin{array}{l}\text { Title and/ or } \\
\text { description }\end{array}$ & $\begin{array}{c}\text { Relevant paragraph(s). } \\
\text { Paragraph numbers in } \\
\text { parenthesis } \\
\end{array}$ & Remarks \\
\hline BAS 20 & $\begin{array}{l}\text { Government } \\
\text { Grants }\end{array}$ & $\begin{array}{l}\text { Initial acquisitions of } \\
\text { emission rights \& } \\
\text { allowances recorded as } \\
\text { assets whose valuations } \\
\text { are subject to } \\
\text { impairment tests. }\end{array}$ & $\begin{array}{l}\text { Government grants could } \\
\text { be influenced by the } \\
\text { politics of the day. } \\
\text { Government can } \\
\text { over/under supply the } \\
\text { rights certificates; } \\
\text { endemic corruptions in } \\
\text { the public sector might } \\
\text { frustrate the system. }\end{array}$ \\
\hline $\begin{array}{l}\text { IFRIC } 5 \text { Jan } \\
2006\end{array}$ & $\begin{array}{l}\text { Decommissioni } \\
\mathrm{ng} \text {, restoration } \\
\& \\
\text { environmental } \\
\text { rehabilitation } \\
\text { funds }\end{array}$ & $\begin{array}{l}\text { Purpose of fund (1), } \\
\text { voluntary \& required } \\
\text { contribution to the fund } \\
\text { (2), geographically } \\
\text { dispersed sites (2), } \\
\text { independent trustees, } \\
\text { accounting for interest in } \\
\text { the fund (7), obligations } \\
\text { to make additional } \\
\text { contributions (10), } \\
\text { contingent liability (10), } \\
\text { reimbursement rights } \\
\text { (BC 12) }\end{array}$ & $\begin{array}{l}\text { Disclosure of the size of } \\
\text { the fund; arms length of } \\
\text { the trustees; plans for } \\
\text { additional contributions; } \\
\text { responsibility for past } \\
\text { degradations; adequacy } \\
\text { of the fund. }\end{array}$ \\
\hline BFRS 8 & $\begin{array}{l}\text { Operating } \\
\text { segments }\end{array}$ & $\begin{array}{l}\text { Core principle (1), nature } \\
\text { of an operating segment } \\
\text { (5), aggregation criteria } \\
\text { (12), quantitative } \\
\text { thresholds (13), } \\
\text { disclosure (20), } \\
\text { profit/loss/ assets and } \\
\text { liabilities (23), } \\
\text { measurement (25), } \\
\text { geographical information } \\
\text { (33) }\end{array}$ & $\begin{array}{l}\text { For a global company } \\
\text { whether its branches and } \\
\text { subsidiaries are } \\
\text { operating in } \\
\text { environmentally } \\
\text { sensitive sectors; and } \\
\text { whether the segment } \\
\text { meets the quantitative } \\
\text { threshold, or whether it } \\
\text { is required to prepare } \\
\text { consolidated financial } \\
\text { statements, and whether } \\
\text { its segments meet } \\
\text { international standards. }\end{array}$ \\
\hline
\end{tabular}

Cont. Table 2 


\begin{tabular}{|c|c|c|c|}
\hline $\begin{array}{l}\text { BFRS/BAS } \\
\text { number }\end{array}$ & $\begin{array}{l}\text { Title and/ or } \\
\text { description }\end{array}$ & $\begin{array}{l}\text { Relevant paragraph(s). } \\
\text { Paragraph numbers in } \\
\text { parenthesis }\end{array}$ & Remarks \\
\hline $\begin{array}{l}\text { BAS 27, } \\
\text { BFRS 3, } \\
\text { BAS 28 } \\
\text { and BAS } \\
31, \text { SIC } 12\end{array}$ & $\begin{array}{l}\text { Consolidation, } \\
\text { investments in } \\
\text { mergers and } \\
\text { acquisitions, } \\
\text { interests in joint } \\
\text { ventures and } \\
\text { associates; } \\
\text { consolidation of } \\
\text { special purpose } \\
\text { entities }\end{array}$ & $\begin{array}{l}\text { Several paragraphs } \\
\text { relate to ownership, } \\
\text { risk, reward, and } \\
\text { significant influence. }\end{array}$ & $\begin{array}{l}\text { Group \& consolidated } \\
\text { statements are prepared } \\
\text { for listed legal entities. } \\
\text { Listed and unlisted } \\
\text { companies might be } \\
\text { sued for violating } \\
\text { environmental } \\
\text { standards in countries } \\
\text { where their segments } \\
\text { operate/operated in the } \\
\text { past. This in turn might } \\
\text { trigger an unbundling } \\
\text { wave. }\end{array}$ \\
\hline BAS 37 & $\begin{array}{l}\text { Provisions, } \\
\text { contingent } \\
\text { liabilities \& } \\
\text { contingent assets }\end{array}$ & $\begin{array}{l}\text { Several paragraphs that } \\
\text { require charging current } \\
\text { earnings for setting } \\
\text { aside normal provisions } \\
\text { and contingent } \\
\text { liabilities. }\end{array}$ & $\begin{array}{l}\text { Absence and } \\
\text { inadequacy of } \\
\text { provisions suggests } \\
\text { earnings inflation } \\
\text { which in turn affects } \\
\text { intrinsic (fundamental) } \\
\text { values of equities. }\end{array}$ \\
\hline BAS 8 & $\begin{array}{l}\text { Accounting } \\
\text { policies, changes in } \\
\text { accounting } \\
\text { estimates and } \\
\text { errors }\end{array}$ & $\begin{array}{l}\text { Accounting policies } \\
(10), \text { retrospective } \\
\text { application (22), } \\
\text { warranty obligations } \\
\text { (32\&33), errors (41), } \\
\text { prior period errors } \\
\text { (49),, impracticability } \\
\text { of retrospective } \\
\text { adjustments (51, } \\
52 \& 53)\end{array}$ & $\begin{array}{l}\text { The extent to which } \\
\text { past earnings require } \\
\text { restatement, and how } \\
\text { this is going to be } \\
\text { shown in past, present } \\
\text { and future financial } \\
\text { statements } \\
\text { (retrospective \& } \\
\text { prospective } \\
\text { adjustments). }\end{array}$ \\
\hline BAS 1 & $\begin{array}{l}\text { Presentation of } \\
\text { financial } \\
\text { statements }\end{array}$ & $\begin{array}{l}\text { Material omissions (7); } \\
\text { purpose of financial } \\
\text { statements (9), fair } \\
\text { presentation (15), } \\
\text { rectification of } \\
\text { accounting policies } \\
\text { (18), going concern } \\
\text { (25), provisions (54), } \\
\text { estimation uncertainty } \\
\text { (125) }\end{array}$ & $\begin{array}{l}\text { Minimum set of } \\
\text { information that must } \\
\text { be included in the } \\
\text { comprehensive } \\
\text { financial statements of } \\
\text { environmentally } \\
\text { sensitive companies. }\end{array}$ \\
\hline
\end{tabular}




\begin{tabular}{|c|c|c|c|}
\hline $\begin{array}{l}\text { BFRS/BAS } \\
\text { number }\end{array}$ & $\begin{array}{l}\text { Title and/ or } \\
\text { description }\end{array}$ & $\begin{array}{l}\text { Relevant paragraph(s). } \\
\text { Paragraph numbers in } \\
\text { parenthesis }\end{array}$ & Remarks \\
\hline$\overline{\text { BFRS } 1}$ & $\begin{array}{l}\text { First time adoption } \\
\text { of BFRS }\end{array}$ & $\begin{array}{l}\text { Accounting policy( 97), } \\
\text { fair value (16), } \\
\text { compound financial } \\
\text { instruments (23), } \\
\text { parents, subsidiaries, } \\
\text { joint ventures \& } \\
\text { associates (24), changes } \\
\text { in decommissioning, } \\
\text { restoration and similar } \\
\text { liabilities (25E), non } \\
\text { BFRS comparative } \\
\text { information (36), } \\
\text { reconciliations (39) }\end{array}$ & $\begin{array}{l}\text { Fair value of } \\
\text { environment related } \\
\text { assets, liabilities and } \\
\text { provisions. }\end{array}$ \\
\hline $\begin{array}{l}\text { BFRS } 7, \\
\text { BAS } 37 \& \\
\text { BAS } 39, \\
\text { BAS } 38\end{array}$ & $\begin{array}{l}\text { Financial } \\
\text { instruments } \\
\text { disclosure, } \\
\text { presentation and } \\
\text { recognition and } \\
\text { measurement, } \\
\text { intangibles \& } \\
\text { impairment }\end{array}$ & & $\begin{array}{l}\text { Disclosure of past and } \\
\text { present environment } \\
\text { related risk(s); } \\
\text { qualitative and } \\
\text { quantitative description } \\
\text { of the effective and non } \\
\text { effective hedging } \\
\text { strategy; fair value of } \\
\text { carbon derivatives and } \\
\text { other environment } \\
\text { related assets and } \\
\text { liabilities. }\end{array}$ \\
\hline
\end{tabular}

\section{FINDINGS AND DISCUSSION}

The findings of the study are consistent with observations of Freedman and Jaggi (2006) and Bebbington et al (2008). In the analysis it is revealed that the phenomena under which the social responsibility and sustainability reports are prepared, who prepares them and whether the reports are subjected to audits remained unclear. More specifically, the annual reports rarely contained nonfinancial quantitative data.

The financial statement section of the annual report is also not very different from the nonfinancial information section. The 2010-11 annual reports of the 65 companies (Appendix-1) were inspected in respect of BFRS 6 (for early 
adoption), IFRIC 5, BAS 37, BAS 8, BAS 32, BFRS 7 and BAS 39. The findings are as follows -

(1) All the annual reports state that the financial statements were prepared in accordance with BFRS (BFRS 1 and BAS 1). The audit report also states that the financial statements were audited in accordance with Bangladesh Auditing Standards.

(2) With regard to BAS 32, BFRS 7 and BAS 39, there is little or no disclosure in the financial statements of the sixty five companies about emission rights and/or carbon derivatives. As regards BFRS 8 and BAS 27, all the companies (for which applicable) are preparing their consolidated financial statements and mention the regions in which they are operating. However, it was not always clear how many segments were consolidated.

(3) None of the companies separately disclosed the amount of normal provisions or provisions set aside for contingent liabilities in respect of the environment.

(4) They do not classify the expenditure [incurred for the improvement of the environmental performance] capital and operating nature. They treat the whole expenditure as operating expenditure.

(5) All the companies prepare their accounts according to the traditional accounting system i.e., there is no determination and classification of environmental expenditures.

(6) The companies disclose only qualitative and descriptive information without any attempts at quantification.

(7) Most of the companies only show positive environmental information and there is no negative information.

(8) The environmental information can only be found either in the Chairman's statement or Director's report. Most of the companies only show their environmental issues regarding protection of the environment, pollution control, planting of trees and other matters. They do not show any information regarding waste generation, conservation of energy, water wastage and recycling of waste, noise nuisance and so on.

(9) Except Summit Power Limited (reported environmental \& compliance cost under general and administrative expenses) none of the companies 
disclose any exact quantitative facts on expenditure incurred and targets set and achieved.

(10) The companies do not maintain any approaches [either physical or monetary approaches] of environmental accounting.

The overall conclusion from the aforesaid financial statements can be summarized as follows. First, from a compliance perspective, it is impossible to conclude that the companies are indeed meeting the requirements of BFRS. Second, the companies did not produce a separate statement on the environment. This observation might be explained by DiMaggio and Powell's (1983) institutional isomorphism imposed by the profession, which puts constraint and pressure on a reporting firm to imitate others and find legitimacy. Finally, from an earnings quality perspective, the implications of the non recognition, non disclosure and inadequacy of provisions for past and present environmental responsibilities points to one direction the inflation of earnings and the intrinsic (fundamental) values of equities.

\section{A Statement of Environmental Assets and Liabilities}

The above discussion leads to two financial reporting policy alternatives that the ICAB might wish to consider. The first option is a mandated separate statement that focuses on the environment. The second option is to require the disclosure of certain elements of information within the existing reporting framework and strengthening the offsetting rule. As the world continues to be preoccupied by issues of environmental degradation, trans-boundary issues get confused with non-trans-boundary issues. The production of a separate statement on the environment would be a preferred policy to decouple trans-boundary issues from non-trans-boundary issues in the context of segment (geographical)

reporting. Table-3 contains some of the elements of the proposed separate statement for the environment. 
TABLE 3

PROPOSED STATEMENT OF ENVIRONMENTAL ASSETS AND LIABILITIES

Statement of Environmental Assets and Liabilities*

As of December 31, 20XX

\begin{tabular}{|l|}
\hline Financial information:- \\
Comparative year \\
Environmental assets:- \\
Cash in trust funds \\
Investments in trust funds at fair value \\
Emission rights held \\
Emission rights held for sale (at fair value) \\
Insurance \& similar products held against environmental risks \\
Contributions to voluntary \& mandatory schemes \\
Inventory of natural \& biological assets \& depletions \\
Investments in air \& water quality \\
Capitalized research \& development \\
Capitalized net site preparation \& restoration costs \\
Environmental Liabilities and uncertain liabilities (provisions or contra asset \\
accounts) \\
Present value of decommissioning, restoration \& rehabilitation \\
Legal and constructive liabilities arising from past events \\
Deferred income from government allocations of emission rights \\
Uncertain liabilities (Provisions or contra asset accounts) \\
Provision for decommissioning, restoration \& rehabilitation (current) \\
Provision for decommissioning, restoration \& rehabilitation of (past) \\
Provision for contingent liabilities from past events \\
Net adjustments to retained earnings for past errors \& material omissions \\
Net surplus (deficit) for current year+ \\
Estimate of net environmental assets (liabilities)
\end{tabular}

*The statement can be accompanied by the disclosure of minimum nonfinancial information such as actual \& ISO permissible standards of emissions, production and disposals of waste, depletion of natural resources \& replacement (forestry), major capital projects that lead to deterioration of air \& water quality and habitat, and urbanization

+ Net surplus (deficit) is arrived after consideration of recurrent income \& expenditure such as interest and dividend incomes from environment related investments, tax rebates and dues, recurrent expenditure on environmental protection, current charges for normal provisions for decommissioning \& rehabilitation, past errors and omissions, current contribution to independent environmental rehabilitation fund \& tax gains and losses arising from hedge activities on environment related products, etc.

The said statement can combine nonfinancial and financial information. The minimum information that ought to be disclosed in the proposed statement can be determined by amending BAS 1 and providing a transition clause in BFRS 1 . The standards that deal with provisions (BAS 37) and changes in accounting policy 
(BAS 8) can be revised to require that provisions for the environment liabilities or asset replacements/impairments be backed by ring fenced cash or cash equivalents. IFRIC 3 and BFRS 6 can be connected, and a standalone standard on environmental sensitive sectors might be necessary.

\section{CONCLUDING REMARKS AND DIRECTION FOR FUTURE RESEARCH}

This paper examined whether financial reporting standards can be used as a device for monitoring the environmental behaviour of environment sensitive companies. The paper reviewed the literature in economics, finance, environmental accounting, and examined the voluntary-mandatory mechanisms of corporate disclosure. The researchers surmise that the proprietary cost (Verrecchia, 1983) and voluntary disclosure mechanism is infeasible for monitoring public goods such as the environment. Mandated environmental public information therefore cannot be discounted on the grounds of voluntary disclosure and Country's beauty contest. Second, a careful examination of the existing ICAB standards provided useful avenues for improving the current set of financial statements, and the production of mandated separate statement of environmental assets and liabilities.

Furthermore, using qualitative and case research methodology the paper examined the annual reports of sixty five local companies that are listed on Dhaka stock exchanges. The researchers find that the social and sustainability reports that were studied do not have standard formats, and the GRI guidelines appear to be inadequate. The financial statements though claim to comply with BFRS they did not enable firms to disclose key environmental information. Consequently, the paper proposed two policy options of either requiring a separate statement of environmental assets and liabilities, or requiring the disclosure of minimum set of environmental information through the existing set of comprehensive financial statements.

The separate statement on the environment that is prepared in accordance with BFRS has a number of advantages, including the decoupling of reputation management efforts of environmentally sensitive firms from their genuine information disclosure efforts. The separate statement emerged from the analysis of the multifactor model in Figure 1, and the analysis of existing financial reporting standards. The proposed statement is consistent with the REA (resource, event, and agent) accounting concept, and certain information can be aggregated for planning and monitoring at sector, macro, regional and global levels. The information can be used by both market and nonmarket (State and pressure groups) actors. Furthermore, since companies are already producing lengthy social and environmental reports the incremental cost of preparing 
the separate statement outweighs the ramifications of climate change and lawsuits on the part of the firms.

There are number of avenues for future research. Replication of this research on other environmentally sensitive sectors might provide corroboration for the conclusions of this paper. Examining the form of association between nonfinancial information and financial information that purports to serve the environment is another avenue. Expanding the taxonomy of environmental accounting in the context of REA, BFRS and other local standards requires a shared database environment. This is another direction for future research.

\section{References}

Aronsson, T. Johansson, P. and Ofgren, K. (1997). Welfare Measurement, Sustainability and Green National Accounting, Edward Elgar Publishing Williston VT, USA.

Barth, Mary E., and Maureen F. McNichols, "Estimation and Market Valuation of Environmental Liabilities Relating to Superfund Sites", Journal of Accounting Research 32 (Supplement) (1994), 177-209.

The Institute of Chartered Accountants of Bangladesh (ICAB) 2006: Bangladesh Accounting Standard (BAS), (1, 8, 20, 27, 28, 31, 37-39) Published in July 2006.

Bebbington, J. Larrinaga Gonzales C. Moneva Abadia, J. (2008). "Legitimating reputation/ the reputation of legitimacy theory", Accounting, Auditing and Accountability Journal, Volume 21 No 3 pp 371-374

The Institute of Chartered Accountants of Bangladesh (ICAB) 2008: Bangladesh Financial Reporting Standard (BFRS), (1, 3, 6-8), Vol. 1, 2\&3, Published in October 2008.

Cabrera, L. (2008). "Widespread Acceptance of IFRS Continues. Is it time for the U.S. companies to prepare for the transition?" The CPA Journal, March, http://www.nysscpa.org/ cpajournal/2008/308/ essentials/p36.htm

Freedman, M and Jaggi, B. (Editors) (2006). "Environmental Accounting: Commitment or Propaganda", Advances in Environmental Accounting and Management, Volume 3, Holland, Elsevier, Ltd.

Global Reporting Initiative (GRI). www.globalreporting.org/information/about-gri/whatis-GRI/Pages/default.aspx, Cited on December 21, 2011.

Haripriya, G. S. (2000). "Integrating Forest Resources into the System of National Accounts in Maharashta", India. Environment and Development Economics, 5, $143-156$.

International Financial Reporting Interpretation Committee (IFRIC), (3\&5), Issued on December 2004. 
Klasson, R. and McLaughlin, C. (1996). "The Impact of Environmental Management on Firm Performance", Management Science, Vol. 42, No. 8, August 1996, pp. 1199-1214

Konar, S., and Cohen, M. (2001). "Does the Market Value Environmental Performance?", The Review of Economics and Statistics, 83 (2): 281-289.

Lang, G. (2003). Policy Applications of Environmental Accounting, The World Bank Environment Department, And Environmental Economics Series Paper No 88.

Verrecchia, R. (1983). "Discretionary Disclosure", Journal of Accounting and Economics 5 pp. $179-194$

Watts R. and Zimmerman, J. (1986). Positive Accounting Theory, Prentice Hall.

APPENDIX 1

\section{LIST OF MANUFACTURING COMPANIES SELECTED FOR THE STUDY}

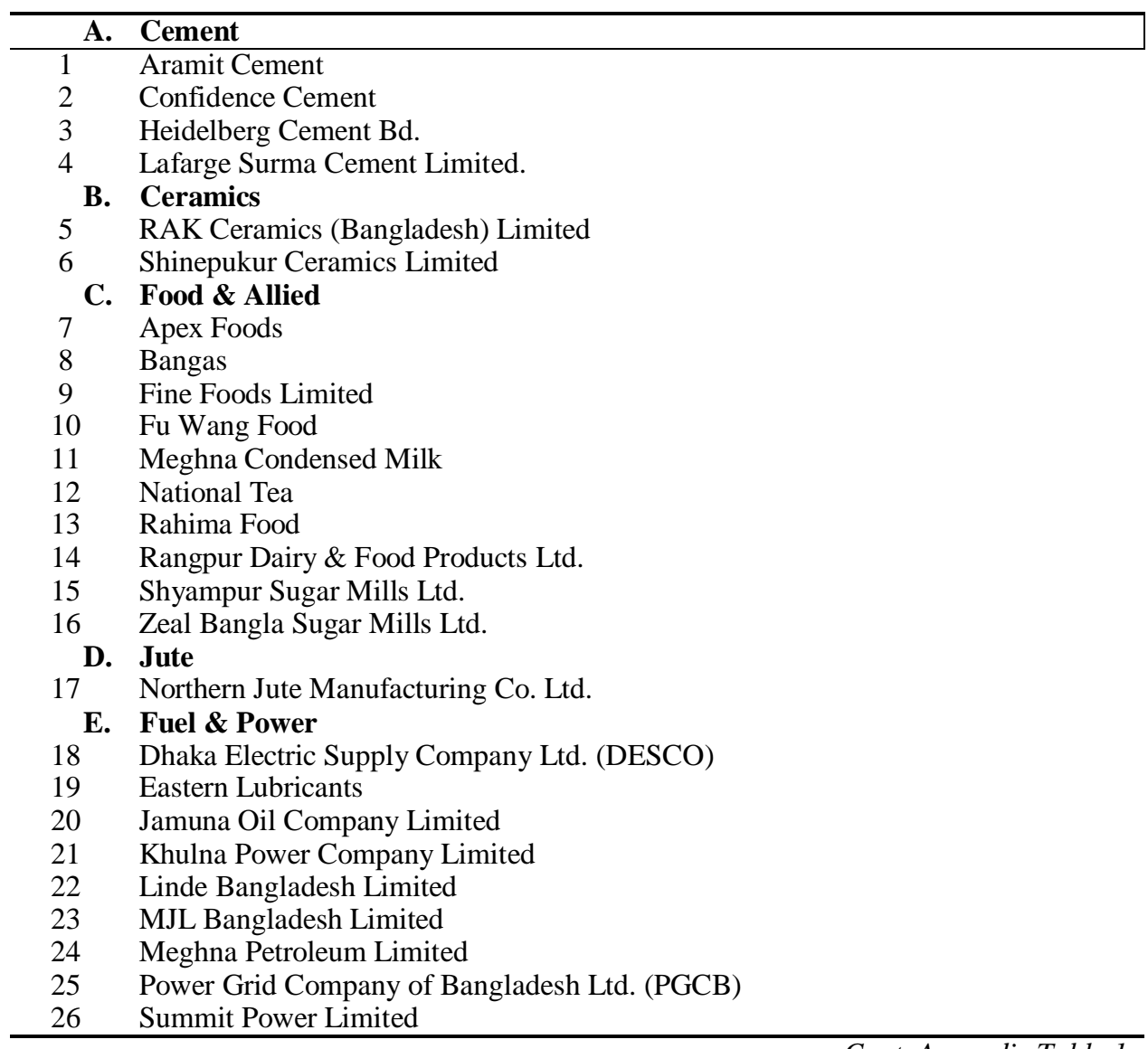


27 Titas Gas Transmission \& Distribution Co. Ltd.

F. Pharmaceuticals \& Chemicals

ACI Limited.

ACI Formulations Limited

Active Fine Chemicals Limited

Beacon Pharmaceuticals Limited

Beximco Pharma

Beximco Synthetics

Glaxo SmithKline

Keya Cosmetics

Kohinoor Chemicals

Libra Infusions Limited

Orion Infusion Ltd.

Pharma Aids

Renata Ltd.

Salvo Chemical Industry Limited

Square Pharmaceuticals Ltd.

G. Tannery industries

Apex Adelchi Footwear Ltd.

Apex Tannery

Bata Shoe

H. Textile

Alltex Industries Ltd.

Anlimayarn Deying Ltd.

Apex Spinning \& Knitting Mills Limited

CMC Kamal

The Dacca Dyeing \& Manufacturing Co.Ltd.

Delta Spinners Ltd.

Desh Garmants

H.R.Textile

Malek Spinning Mills Ltd.

Metro Spinning

Mithun Knitting

Modern Dyeing \& Screen Printing Ltd.

Prime Textile

Rahim Textile

R.N. Spinning Mills Limited

Saiham Textile

Sonargaon Textiles

Square Textile

$\begin{array}{ll}64 & \text { Stylecraft Limited } \\ 65 & \text { Zahintex Industries Limited }\end{array}$ 